„Bohemistyka” 2020, nr 3, ISSN 1642-9893

Jaroslava JANÁČKOVÁ

DOI: $10.14746 /$ bo.2020.3.1

Univerzita Karlova, Praha

\section{Karel Havlíček a Josef Václav Frič ve střetu o Ladu Niólu ${ }^{1}$}

Keywords: Czech literary, literary criticism, Karel Havlíček, Josef Václav Frič

Klíčová slova: česká literatura, literární kritika, Karel Havlíček, Josef Václav Frič

\section{Abstract}

The article interprets Uprimné mínení o almanachu Lada Nióla, written by Karl Havlícek in Brixen on December 23 and 24, 1854, in which Havlícek rejected the romantic tendencies of almanac initiated by J. V. Fric in the spirit of literary realism. The author describes how Havlícek's criticism concerned individual authors and the contribution of the almanac. Uprimné mínení... by Havlícek could not join the discussion that began after the publication of Lady Nióla in newspapers and discussion that began after the publication of Lady Nióla in newspapers and
magazines. Only a narrow circle of literary actors from the 1950s could meet him privately. The author states that Fric himself distorted Havlícek's criticism of his almanac when he reported it in his later memoirs (Pameti), thus contributing to the fact that Uprimné míneni o almanachu Lada Nióla was not yet considered in the history of Czech literary criticism in the place that Havlícek deserves.

Článek vykládá Upřimné mínění o almanachu Lada Nióla, sepsané Karlem Havlíčkem v Brixenu ve dnech 23. a 24. 12. 1854, jako významný literárně kritický text, ve kterém Havlíček odmítl romantické tendence almanachu iniciovaného J. V. Fričem v duchu intencí literárního realismu. Přibližuje, jak se Havlíčkova kritika stylizovaná částečně jako osobní list, částečně jako náčrt recenzního posudku vyrovnávala s jednotlivými přispěvateli a př́spěvky almanachu. Do relativně bohaté veřejné diskuse, která po vydání Lady Nióly následovala v novinách a časopisech, Havlíčkovo Upř́mné mínéní... vzhledem k cenzurní situaci svého autora vstoupit nemohlo, soukromě se s ním mohl seznámit jen úzký okruh aktérů pražského literárního dění 50. let 19. století. Článek v závěru konstatuje, že sám Frič Havlíčkovu kritiku svého almanachu zkreslil, když o ní informoval ve svých pozdějších Pamétech, a prrispěl tak $\mathrm{k}$ tomu, že Uprímné minění... nebylo dosud zařazeno $\mathrm{v}$ dějinách české literární kritiky na místo, které si Havlíčkův kritický výkon zasluhuje.

Text vznikl v rámci projektu GA ČR 17-13671S Publicistika a korespondence Karla Havlíčka (hl. řešitel doc. Mgr. Robert Adam).
Na samém konci roku 1854 vyšel v Praze almanach Lada Nióla, který se Fričovi podařilo vydat jen pár měsíců potom, co byl v květnu propuštěn z vězení v Komárně. Havlíček, v ten čas ještě v Brixenu bez jasné vyhlídky na návrat do Čech, podnikl riskantní manévry, aby se mu slavnostně vybavená publikace dostala tajně do rukou - a aby neprodleně rukopis jeho Upřimného mínění o almanachu Lada Nióla, datovaný 23./24. 12 Brixen, putoval do Prahy. ${ }^{2}$

Proč ten spěch?

$\mathrm{V}$ rolích původce almanachu a jeho prvního kritického čtenáře se setkali dva političtí oponenti, oba krutě potrestaní za diferencované politické aktivity v letech 1848/1849: liberální demokrat a radikální demokrat. Přitom Havlíček mohl zazlívat Fričovi, že opožděným květnovým povstáním 1849 v Praze vyvolal přitvrzení již započaté represe a zásadně tak zbrzdil kroky k ustavování demokratických poměrů v Čechách navzdory prohrané revoluci. Jenomže Frič svého největšího protichůdce přežil (1890) a přičinil se o to, že Havlíčkovo Uprimnné mínění nepodlehlo zkáze, ,jenom" zapomnění.

Eminentně politický kontext nebyl Havlíčkovi jediným podnětem $\mathrm{k}$ tomu, aby spěchal se svým vlastnoručně psaným Upř́mným míněním a s jeho odesláním hodnověrnému příteli do Prahy. Zhruba deset

\footnotetext{
${ }^{2}$ Zmíněný autograf střežil celá léta MUDr. J. Podlipský a jeho dědicové, dnes ho chrání Státní okresní archiv v Havlíčkově Brodě. Ještě v privátní péči bylo Upřimné minění, jak ho budeme zkráceně jmenovat zde, podvakrát uveřejněno (s odbornou péčí J. Holečka v druhém ročníku „Časopisu pro moderní filologii” 1912, a ještě 1935 - v prvním čísle roč. 1935 Batova časopisu „Zlín”; toto druhé - nepřesné uveřejnění kriticky glosoval „Zvon” (1935, č. 35). Až teprve třetím vydáním, za péče o národní klasiky po druhé světové válce, vstoupilo Upřimné mínění na půdu Havlíčkových spisů. Ve výboru Havlíček Borovský 1955 (s. 82-89) ho tenkrát - na své riziko a bez náležité odezvy - poprvé otiskli moderně erudovaní vydavatelé J. Bělič a J. Skalička. (K tomuto textovému znění budou zde odkazovat naše citace uvedením roku 1955 a stránky). - Pozdní vtažení Havličkovy kritiky Lady Nióly do vrcholů autorových literárněkritických aktivit bylo v kontextu vyvolaném poklonkováním J. V. Fričovi a radikálním demokratům po roce 1948 odvážnou výzvou. Př́ ní však bohužel zůstalo, do vědecké reflexe ani popularizace Havlíčkova odkazu tenkrát ani později nepronikla.
} 
let předtím se zásadní kritikou Tylova Posledního Čecha zasloužil o postupné přeorientování literárního života od emocionality k uvážlivému čtenářství i psaní, opřenému o racionální pozorování přítomného světa. Ted' se natolik vžil do úlohy znalce romantismu, který propagoval Ladou Niólou Frič, aby tento ideál veřejně odmítl a nabídl za něj směřování $\mathrm{k}$ realismu, ne sice dost jasně pro danou chvíli formulované, ale přesto zřetelné. Ačkoliv se tak vyjádřil mezi prvními činiteli literárního života, jeho neuveřejněné „mínění” sotva mohlo ovlivnit zásadní debatu vedenou v časopisech o tom, co Frič propaguje (a které slibnější možnosti v současném literárním poli zanedbává). A když se toto umlčení protahovalo (také s Fričovým přispěním) ještě do let po Havlíčkově smrti (1856), sotva je možné počítat s tím, že se Upřimné mínění mohlo činně uplatnit v dobovém přijetí Fričova almanachu a v jím ovlivněném ,významu”. Díky dodatečnému otištění rukopisu ale v historické paměti trvá, a jí se tu při evokaci literárního pole uprostřed bachovské éry dovoláváme.

Snad všecka pojednání o Havlíčkovi jako literárním kritikovi zatím konstatovala, že intenzivní nasazení v denním politickém tisku 1846-1851 a pak internace nedovolily novináři, natož pak umlčenému talentu věnovat se kritice literatury, v níž zpočátku oslnil. Se znalostí Upřimného mínění se jeví Havlíčkova účast v násilně ztlumeném literárním proudění jako něco, co vyvěralo z jeho bytostných vloh a z potřeby účastnit se literárního života. Byt' je v daný okamžik internován v Brixenu a jeho možnosti vstoupit do veřejné literární komunikace jsou silně limitované a znamenají pro něj riziko, s pomocí přítele Podlipského překonává překážky, na první pohled nepřekonatelné: dobere se hned zatepla výtisku Lady Nióly z Prahy, rychle (možná přes noc před Štědrým dnem 1854) vypracuje náčrt své úvahy o almanachu a zajistí jeho doručení zpět do Prahy MUDr. Podlipskému.

Jako jediný ze známých kritiků/recenzentů, kteří o almanachu psali doma v časopisech (a vedle L. Štúra, který almanach s nadějí čekal a vzápětí zatratil, jak víme z jeho dopisů Fričovi ze Slovenska od prosince 1854 do února 1855), posuzuje Havlíček Ladu Niólu v jisté úplnosti a podle jednotných kritérií. Respektuje almanach jako publi- kaci programní, otevřenou literatuře světa, zaměřenou k romantismu, který vyznačuje zalíbení ve svátečnosti, výjimečnosti, v aristokratických pózách lyrických mluvčích, ochotných shlížet ze svých výšin k obyčejnějšímu čtenáři - za podmínky, že je tento čtenář obdivuje a snaží se upínat svou obraznost k jejich imaginaci.

Názorová pozice K. Havlíčka je protikladná ideálu romantické literatury, nabízenému Ladou Niólou. O osm roků starší než Frič, jeho politický protivník z revoluce 1848/1849, prošel Havlíček školou uměleckého klasicismu, který kultivoval smysl pro rozumové poznání skutečnosti a pro uvážlivé jednání. Má vrozený dar humoru a sdělné řeči, nastavené $\mathrm{k}$ hovoru s čtenářem, a takto již předtím kultivované při víceleté tvorbě novin.

Nastíněnou představu čtenáře uplatnil jako výchozí hledisko v Upřimném míněni o Ladě Nióle. Vưči mnoha př́spěvkům (nejen v oddílu věnovaném básním) se vymezoval otázkou, zda jim čtenář může rozumět, jestli je schopen dobrat se smyslu veršů plných zašifrované obraznosti. Nad Sojkovým oblakem se prrímo hrozí:

Jak najdu v básni patrný důkaz, že skladatel nic nemyslil, nýbrž jen mlel hubou neb perem, již ji odsuzuju vždy, a to právem (Havlíček 1955, s. 83).

Vzápětí svou kritickou poznámku o autorovi, kterého cení spíš jako koketu než jako tvưrce, uzavírá:

Básník dle mého nezvratného mínění musí být rozumná hlava a ne trouba (Havlíček 1955, s. 83-84).

V první části svého vyjádření popustí Havlíček podvakrát uzdu familiárnímu tónu. Tak v poznámce č. 3 se svěřuje čtenáři s tím, jak se musel přemáhat, aby pokračoval v čtení Kolářova př́ispěvku:

Prosím Vás, nepatří-li k tomu hrdinská mysl, čísti dále dlouhou báseň, když hned v prvních řadách stojí tak kolosální nesmysl, že bouří pluk duchů spících, já ale čtu přec dál a zakousnu zas druhý, kde Helena „z lože vylítne”, přec ale proto ještě spí!!, pak jsem ještě strávil „ten kyprý nahý prs” - pak ale jsem si myslil, že jsem dost pracoval (Havlíček 1955, s. 83). 
Nato pak v poznámce č. 10 osobně kárá syna F. Palackého „Honzu", že almanachu dal k uveřejnění, co nesrozumitelného napsal ve verších pod pseudonymem Smil o světobolu („Weltschmerz”).

Co kritikovi, který nedávno v roli satirického básníka dokončil Krále Lávru, principiálně vadí, je povýšenost přispěvatelů Fričova almanachu vůči jednoduššímu čtenáři a vůči vlastnímu předchůdci na domácím poli, jakým byl F. J. Rubeš, tvůrce deklamovánky a humoresky. K němu Havlíček choval větší uznání, než jaké mu přiznal Vorlíček (prý Tyl naučil české lidové vrstvy číst beletristickou prózu, Rubeš jim přiblížil řeč veršovanou). „Takoví ti Vorlíčkové, Sojky, Straky," ironizuje Havlíček pyšné mladé přispěvatele z Lady Nióly, „nasazují u nás tón tak vysoký, jako by oni sami byli Mickiewiczi a Lessingové. Chlap píše o Rubeši a přizná se sám, že o jeho životu mu málo známo bylo. Jako by žil v Americe". Ostatně prý Vorlíčkův životopisný nástin v almanachu ,,je zbytečná práce”, uzavírá Havlíček útočně:

[...] skutečné ocenění Rubše to přece není, a pouhá rekomendace, tu by potřeboval spíś Vorlíček od Rubše než Rubeš od Vorlíčka (Havlíček 1955, 83-84).

Namyšlenost vytkl první kritik také názvu almanachu: chce prý působit učeně a tajuplně, ale ,míchati litevskou (beztoho krom toho silně podezřelou) mytologii se slovanskou, a i kdyby toho nebylo, je titul na každý způsob hledaný, manerýrovaný" (Havlíček 1955, s. 82).

Ačkoli dříve nešetřil chválou na to, co kde napsala B. Němcová, $\mathrm{v}$ Upř́mném mínéní je vưči její pohádce $\mathrm{i}$ povídce $\mathrm{v}$ almanachu zdrženlivý. Již sama její účast na něm mluví o př́iklonu jedinečné vypravěčky k vlivu Fričovu.

Ta pohádka $\mathrm{O}$ dvanácti měsíčkách je velmi hezká, ale ještě by byla lepší, kdyby byla celá psána česky (Havlíček 1955, s. 84-85).

Použité slovenské výrazy prý vadí Čechovi, uplatňuje kritik své zaujetí proti slovenské odluce, ,,a pro Slováky by muselo být všechno slovenské". S jistou ostražitostí tak Havlíček nadhazuje, jestli snad Němcová nepřijímá Fričovu výzvu povznášet současnou literární práci propojením inspirací z H. Heina se slovenskou písní a tak ladit struny literární tvořivosti k slovanskému romantismu. Podobně, zdá se, má autor Upř́mného mínění iniciátoru Lady Nióly za zlé, že nejlepší česká vypravěčka toho času napsala pro almanach (třeba na jeho žádost?) novelu s tajemstvím (Sestry). Tento žánr, ukotvený ve vypravěčství dávném a udržovaný v novodobé literární komunikaci pro svou napínavost, byl pro Havlíčka, jak ukázala jeho už o deset roků starší kritika Posledniho Čecha, zastaralý, vypočítaný na nevybíravé čtenáře. Nad Sestrami dokonce zauvažoval, že to mohl být vzhledem k vynikajícímu vypravování nejlepší příspěvek almanachu. „Ale musíte sám říci," dovolává se souhlasu sobě blízkého čtenáře (mohl jím být MUDr. J. Podlipský), ,že ty věci se pro každou zem stejně hodí a že jste již mnohokrát jistě cosi takového četl" (Havlíček 1955, s. 86).

Bedlivou pozornost věnuje Havlíček ve svém Upřimném míněni textům nadepsaným Fričovým jménem, pseudonymem či jen šifrou. Jen malou část z nich hodnotí jako výkony hodné pozoru. Tak ho zaujala báseň Velikáni, podepsaná zkratkou St. (jinde zastupuje jméno Frič), a vyslovuje přání poznat autora:

Velikáni je něco, a dobře pracováno, ale taky je trochu těžko zcela jasně rozumět, co mínil pan básník. $\mathrm{O}$ tom bych rád věděl, kdo jest: $\mathrm{z}$ této básně, je-li myšlénka jeho vlastní, a z toho bohdanečského dopisu objevuje se přece duše (Havlíček 1955, s. 83).

Co z Fričových příspěvků v almanachu zcela odmítá, jsou texty programní. Jde o vstupní lyrické básně (,Jeho Zmrtvýchvstání jest item podobný božský nesmysl, zas jen nevkusné nahromadění tropů, ale žádné idey”). Nejhůř v Havlíčkově „mínění” dopadla próza Život sváteční. Frič v ní doporučil ústy básníka jako nosné zdroje př́iští české literární tvorby slovenskou lidovou píseň, umocněnou podněty z poezie H. Heina ve slovanský romantismus. Ten posuzovatelé Lady Nióly, zaujatí proti „cynickému” Heinovi, odvrhli. Havlíček měl k odmítnutí Fričovu „romantismu” jiný důvod: jemu ležela na mysli národní specifičnost literatury vůbec a české zvláště.

V posouzení Života svátečního podlehl jinak uvážlivý kritik osobní nevraživosti vůči Fričovi: zatratil i samu jeho vůli se jako básník 
prezentovat. Jako by nevěděl, že literární pole v každém čase zaplňují spíš talenty druhého než prvního řádu, a že těch prvních je k literárnímu životu i k vývoji slovesného umění zapotřebí jako soli. Ztratil ze zřetele, že se vyjadřuje k výkonu jednoho talentu v literárním životě již etablovaného, že není na něm, aby soudil mladého muže s enormní ctižádostí stát se první autoritou a hybatelem české literární scény, sotva se této možnosti poprvé chopil. Prý nemá žádný talent:

Život sváteční je pro mne důkazem, že z mladého Friče nebude nikdy pravý básník. Ze všeho se u něj jeví jakási démonická ctižádost, ta sice může člověka časem došroubovat $\mathrm{k}$ tomu, že něco obstojného na svět přivede: ale pravá matka dobrých prací beletristických zůstane přece jen zalíbení v tvoření samém. Když tak přečte člověk ten dlouhý Život svátečni - a je k tomu mnoho trpělivosti potřeba, protože skoro nic neláká k dalšímu čtení -, zeptá se celý vyjeven: Co to je? Nač? Napsal to kvůli té jedné dětské pohádce, neb chtěl jen mluvit o Heine, neb chtěl odbýt svou známost slovenských písní a obyčejů? Konečně po delším rozmýšlení vidíme, že se mu jen vůbec o to jednalo, něco napsat (Havlíček 1955, s. 85).

Jako zkušený publicista ví Havlíček v ty chvíle, že co píše, může se za tisku i pozměnit. Jistých stylisticky komunikačních variací se dopouští sám. Upřimné mínění píše stř́ídavě jako dopis důvěrnému příteli a jako koncept literárního posudku; pošle ho však jako osobní psaní. Snad i vzhledem ke svým ústupkům vůči „,normě” kritického posouzení literárního díla a $\mathrm{v}$ obavách $\mathrm{z}$ úředního postihu nadepsal svůj rukopis Upř́mné mínění o almanachu Lada Nióla. Substantivum „mínění” se ještě v Přričním slovníku jazyka českého vykládá jako „přesvědčení, názor, úsudek, soud, domněnka”, poukazuje tedy dodnes k subjektu mluvčího. Adjektivu „upřímné” se pak podle téhož slovníku z nám blízkého času přisuzuje také význam ,otevřené”. Nadpisem svého autografu tedy Havlíček sliboval MUDr. J. Podlipskému a nějakým společným osobním známým ,svůj otevřený názor”. Během psaní možná pozapomněl, že jeho osobní výhrada k Fričovu nedostatečnému talentu $\mathrm{v}$ textu, který zasílá druhé osobě, zůstává, a tím se stává potenciální urážkou osoby třetí, jím označené vlastním jménem. Jedinou polehčující okolností tu snad zůstává, že osobní odsudek je skryt v písemné zásilce důvěrnému příteli jich obou.
Po onom př́krém výroku proti svému protichůdci se Havlíček vrací v Uprímném míněni do role uvážlivého hodnotitele zbylých př́spěvků v almanachu. Ale už má přiostřeno. Zmínili jsme námitky vưči povídce Sestry od B. Němcové. Příspěvek $Z$ Venecie postaví do neprríznivého světla už tím, že o jeho autorovi předešle:

Ten pan Sojka, »s duchem byronským«, jak o sobě praví, telátko... ( Havlíček 1955).

Ale nebyl by zkušený publicista a ironik, kdyby na závěr svého Upř́mného mínění... nezopakoval svou chválu na jednu satiru ve formě dopisu ( $Z$ Bohdánče), která Fričův almanach uzavírá. Autor satiry ( sám původce almanachu), se tímto výsměchem Českému muzeu solidarizuje s mnoha rozličně laděnými kritiky instituce, která kolaboruje s bachovskou represí. Takto podané ruce Havlíček rozumí: nad poslední nedlouhou satirou v Ladě Nióle vzdává chválu almanachu, od kterého se předtím v Upř́mném mínění... až na výjimky distancoval. Německý frazeologický výrok „Ende gut, alles gut”, který cituje v samém konci svého rukopisného posouzení, se možná pro Havlíčka osobně lomí do úsměšku.

Na rozdíl od dalších recenzentů Lady Nióly (sotva koho z nich bude číst, a nejvýš jen dodatečně, když už se celá česky vedená veřejná debata o almanachu uzavře) se Havlíček zcela věcně staví k Puškinovi i k Heinovi, k nimž se Fričův almanach přihlásil jako k uměleckým autoritám či vzorům odjinud. Nepohoršuje ho žádný z nich. Jen podotkne, že ani $\mathrm{v}$ jednom př́ípadě nemá po ruce originální text pro posouzení překladu. K Bendlovu českému „Bakčiserajskému fontánu” dík své znalosti ruské literatury a ve jménu svého programu slovesného umění národně reprezentativního poznamenává:

Že ale má Puškin hezčí věci na překládání, ale taky těžší (totiž básně v duchu ruském psané), to je jistá věc (Havlíček 1995, s. 83).

Své kritické vyjádření k Ladě Nióle píše Havlíček v předpokladu, že rukopis (sebou nepodepsaný) zašle co možná neprodleně pražskému př́teli bez udání jeho jména i adresy. Nasnadě je tedy stylizace prripomínající osobní dopis, sem tam se přímo obracející k druhé nej- 
menované osobě. Takto je čtyřstránkové Upřimné mínění..., datované Brixen 23/24.12.1854 (i díky komunikační tísni, za níž vznikalo), disponováno oslovovat každého, kdo je bude číst. Má blízko k textu publicistickému: vlastnímu pojednání předchází název, a ne oslovení, patřící k osobnímu psaní. Na rozdíl od článku, který by vyšel v novinách/časopisu, však musí potenciální zájemce o čtení požádat majitele rukopisu a ten mu zase pak vrátit. (Možná jen díky tomu, že původní adresát na svém vlastnictví trval a jeho dědicové to respektovali, se Havlíčkův autograf uchoval až po naše dny.)

Dlouhodobou eliminací Havlíčkovy účasti v dobové recepci Lady Nióly (a té události jako celku) se stornoval jeden podstatný program českého literárního života a práce, koncipovaný nikoli z pozice snílka z cizích luhů, jako byl J. V. Frič, ale z uvážlivého obzírání českého světa a jeho palčivých potřeb. Upřimné mínění formuloval iniciátor české politické publicistiky z let 1846-1851 a její uznávaný hrdina, navíc populární satirik, od prosince 1851 izolovaný od veřejného života v Čechách internací v Brixenu na dobu neurčitou. V prosinci 1854, kdy se vyjadřuje k Fričovu počinu, je už netrpělivě nakročený $\mathrm{k}$ návratu domů.

Tam ho však nečeká svoboda, ale další pronásledování. Diskuse o Ladě Nióle, probíhající v domácím tisku, se tedy nezúčastní. To, co tam z ní lze číst, napovídá, že by jeho Upřimné míněni bylo posílilo

${ }^{3}$ Daleko radikálnější nesouhlas s romantismem projektovaným v Čechách Fričem vyjadřoval L. Štúr, almanachem pobouřený, v psaní z 11. února 1855: „kampak jsi zabloudil, Jozefe? Myslíš-li vést svět slovanský na smradlavé výpary hnijícího západního světa? [...] Nikdy mi ovšem nenapadlo, že bys Ty tam směroval, odkud jen morový duch vane, jehož světu našemu, pakli žiti chce, štítiti se třeba." Štúr zapřísahal druha z Čech, aby „k jiným studním spěchal občerstvit se, a pro všecko Tě prosím, abys, nechaje vyzáblin romantických, obrátil se k študiím poesie i života slovanského a pak také k seznání snah starožitných klasických..." (Štúr 1956, s. 326). Pro Čechy byl slovanský romantismus slučitelný s inspirací romantismem západním (pro Ladu Niólu ho reprezentoval jmenovitě Heinrich Heine), kdežto Štúr jakoukoli návaznost tohoto druhu odmítal; doporučoval naopak domácí/slovanské od cizího/západního separovat, aby se domácí nenakazilo. (To zčásti rezonovalo i v Čechách.) odpor proti romantismu, jak ho propagoval Frič. Doplnilo by v dobovém společenském povědomí názory šířené časopisem Obzor. Ten v několika příspěvcích z května 1855 usvědčil Friče, že neuznává, a dokonce ani nezná ty činitele $\mathrm{v}$ domácím literárním poli, upjaté k objevování národní specifičnosti, a jen slepě doporučuje vzory cizí. ${ }^{3}$

Dobový kritický ohlas Lady Nióly nabízí prŕmo lichotivý obraz českého literárního života uprostřed padesátých let. Mezi prvními se ze zcela osobních důvodů ozval recenzent odlišného vkusu F. M. Klácel, cítící se právě poškozen nedávným upozaděním kamsi do okrajů literární scény (solidarizovat se s perzekuovaným, byt’ z jiných důvodů než Frič, chápe jako výhodné). Odmítavé stanovisko $k$ almanachu vyslaly z Vídně Slovenské noviny, placené za to, aby české literární pole dusily. Argumentují obranou platných morálních hodnot, které prý Lada Nióla rozvrací. Shodou št’astných náhod se k Fričově iniciativě v celé sérii př́íspěvků vyslovil v květnu 1855 časopis Obzor, vydávaný sice jen po několik měsíců, ale disponující silami schopnými obzírat a posuzovat literární pole ve směru národní specifičnosti. V jeho redakci se v blízkosti K. J. Erbena a K. B. Štorcha etabluje kritik V. Zelený. Ten v několika uvážených krocích předvede, že sebestředný Frič ignoruje slibné výkony současné literatury v objevování národní specifičnosti a reprezentativnosti, a jen jí vnucuje vzor cizorodý.

Uprímné míněni Havlíčkovo, v čas prvotního ohlasu Lady Nióly neslyšitelné, vrhalo do živé pře jiné podněty. A že vycházely od prvního Fričova politického protichůdce, nesla je výrazně kontrastní představa literární práce a způsobů čtení. Když tomuto zakladateli politické žurnalistiky a statečnému satirikovi z Brixenu po letech přibývalo po náměstích českých měst rok od roku pomníků, nebyl to pro Friče důvod, aby aspoň jeden z Havlíčkových dosud neznámých článků proti němu zůstal u svého majitele, který ten rukopis držel (přinejmenším od Havlíčkovy smrti 1856) pod svou kontrolou?

Stárnoucí iniciátor Lady Nióly mohl být spokojen, že hlas předního politického protivníka v odezvě na jeho almanach je umlčen. Přesto se však rozhodl k dalšímu ,reinterpretačnímu” gestu. 


\section{Lada Nióla ve Fričových Pamětech}

Když se po víceletém pobytu v evropských zemích mimo Rakousko vracel roku 1879 domů, potřeboval J. V. Frič učinit nejeden krok, aby svou pověst zbavil prohřešků z minula a mohl působit v českém veřejném životě jako jistá autorita. Osobním ujednáním s Juliem Grégrem, vůdcem mladočeské strany a majitelem „Národních listů”, se stal tajným redaktorem těchto vlivných novin. Zajistit si renomé $\mathrm{v}$ široké kulturní veřejnosti a $\mathrm{v}$ národní paměti, $\mathrm{k}$ tomu nesebekritickému snivci pomohlo pero dychtivé psát. Dva díly obšírných Pamětí (1886 a 1891) byly s to přesvědčit i jedince, kteří nectili Fričova dramata a básně, aby tomuto muži netuctového jednání a krkolomného běhu života přiznali literární talent. V širší veřejnosti se navíc memoáry ctily jako pravdivé sdělení pisatele o dosavadním běhu vlastního života. Teprve školení historikové časem začali osvětlovat, že tento žánr autobiografického vyprávění vycházel u Friče vstříc potřebě stárnoucího ,romantika” zbavit svůj životní př́iběh, bohatý na improvizace a bezděčné i vědomé zámlky a prohry, všeho nejasného, ne-li problematického, a vybavit ho pro budoucí čtenáře kroky přitažlivými, ne-li př́íkladnými. (Vypravěč memoárů se nevrací k mladším etapám svého života, aby vyložil, co ho potkalo a jak si v té které situaci vedl, ale aby sama sebe představil tak, jak chce, aby sympaticky ožíval v myslích pamětníků: nejen on sám, ale i akce, jichž se osobně účastnil, hnutí, k nimž patř́ival.)

Na to, že v Pamětech musí podat i př́iběh Lady Nióly ve své interpretaci, ho možná upozorňoval zvýšený zájem pražské kulturní veřejnosti a publicistiky let osmdesátých o almanachy vydané v padesátých letech. Interních diskusí, které tento zájem prriživovaly a snad i korigovaly, se Frič třeba na pozvání osobně účastnil - při nich mohly zaznít otázky pamětníků, na které sám třeba odpovídal vyhýbavě anebo nerad.

V nedlouhé pasáži druhého dílu Pamětí Frič bagatelizuje snad všecko, oč mu po návratu z komárenské pevnosti do Prahy zjara 1854 v Ladě Nióle šlo. Hrstka přispěvatelů prý byla zatím bez valné literární zkušenosti, šlo tedy jen o vzkříšení n á r o d n í poezie - ,a přece nám vyčítali cizáctví!" (Frič 1891, s. 497). Naštěstí se dočkali i uznání, almanach přivítal F. M. Klácel na Moravě a prof. Hanuš v Praze. Iniciátor almanachu zato musel být pochválen žijícími klasiky. Tak prý redaktoru Fričovi vzkázal někde z venkova blahopřání J. K. Tyl, pro předpokládaný druhý ročník almanachu mu přislíbil svůj prŕíspěvek K. J. Erben. Jak přispěl podle Pamětí k př́íznivému uvítání Lady Nióly Karel Havlíček (její zatím umlčený zásadní kritik)? „a rovněž Karel Havlíček v privátním dopise dru Podlipskému dal mi gratulovati, když mu byl prrítel nový almanach zaslal př́ímo do Brixenu". Jak je vidět, v pozdním převyprávění uchoval Frič z reálného průběhu členité akce, která kdysi proběhla od konce roku 1854 do následujícího jara a Havlíčkovo Uprimmé minění... podmiňovala, jen Podlipského doručení Lady Nióly do tyrolského vyhnanství a Havlíčkovu pochvalnou odpověd' v osobním psaní témuž zprostředkovateli. Zato však zásadně změnil obsah a ráz Havlíčkova „dopisu” ve svůj prospěch: jemu prý i sám Karel Havlíček k vydání almanachu blahopřal (gratulací se vykazovat nemusí, když byla podle jeho výmyslu adresována Podlipskému).

V oné části druhého dílu svých Pamětí, věnované převyprávění všeho, co si pamatoval o prvním přijetí Lady Nióly, ještě stačil zestárlý Frič sdělit, že Lada Nióla se mladým líbila, ale starým po chuti zrovna nebyla (a taky jeden z těchto ,starých”, prof. Staněk, Fričův strýc, prý „naprosto selhal”, když v jednání stran vydání druhého ročníku almanachu něco nepředal, něco zatloukl).

Proč koncem života podal Frič o Ladě Nióle „,vzpomínku” tak vzdálenou záměrům a vzruchu, který almanach v půli padesátých let sledoval a vyvolal? Roli v tom nesporně hrála vrozená záliba v lichotivé autostylizaci, kterou mu kdysi nad Životem svátečním př́ikře vyčetl K. Havlíček. O důvod víc, aby se na odezvu Lady Nióly a hlavně na Havlíčkovu kritickou účast při ní zapomnělo. Přihrával také pozdní věk, kdy se i Fričovi, dlouho schopnému žít v provizoriích a improvizacích, zachtělo zklidňujících jistot. Proč raději neproměnit příběh své Lady Nióly tak, aby se v něm účast K. Havlíčka, v mládí nejobáva- 
nějšího „konkurenta”, nezredukovala na jedno blahopřání Fričovi, tlumočené navíc jen v dopise společnému známému? Vždyt' Upřimné mínění... zatím nebylo publikováno. Pamětníků události se mohlo nedbat; šlo v první řadě o jedince v přátelských kontaktech s MUDr. J. Podlipským, s jeho rodinou a dědici, a těch nutně bylo málo a s časem jich ubývalo. Že tím svou účast v literárním životě uprostřed padesátých let, sotva se dostal z vězení dík jedné amnestii, připravil o položku z nejzávažnějších? Zato se starý muž zbaví jednoho počinu, jehož třpyt tenkrát vážně zproblematizoval úhlavní protivník K. Havlíček. Zásadní manipulaci s vlastní zkušeností si Frič dovolil díky pětadvacetileté prodlevě, která od zažité události uplynula. Počítal s tím, že nejen důvěřiví čtenáři, ale i historikové a dějepisci literatury mohou dát a dají přednost jedné snadno dostupné knize Pamětí (nedlouhé pasáži v nich) před pročítáním několika časopisů a dalších dostupných pramenů v domněnce, že uvážlivý autor vystihl někdejší zásah Lady Nióly do literárního života přesněji, než by to dokázal profesionální vykladač ze svého mnohem delšího, navíc několikerého odstupu.

Iniciativní krok k rehabilitaci Havlíčkova Upřimného mínění... a k ocenění této úvahy v dobové recepci Fričovy Lady Nióly učinil K. Kazbunda v třetím svazku své havlíčkovské biografie, vydané se značným časovým prodlením po dokončení rukopisu. Ačkoli se úvodem k tomuto podrobnému obrazu odřekl sledovat Havlíčka jako spisovatele a literárního kritika, přece se třetí kniha jeho biografie dotkla Havlíčkovy polemiky s Fričem stran Lady Nióly (a Fričovy odvety za ni v Pamětech). Tím Kazbunda upozornil na téma za letitého kultu radikální demokracie tabuizované a dotud patřičně nerevidované. Bohužel nestačil jedno heroické gesto K. Havlíčka vnést do evokace jeho života na konci internace v Tyrolích; tak se i v jeho monografii mluví o Havlíčkovi neustále skličovaném opakovanými nezdary př́buzných a přátel z jednání na nejvyšších místech ve Vídni ve prospěch jeho návratu domů. Kdyby se do těchto únavných beznadějí, s nimiž se Havlíček koncem roku 1854 svěřoval prrátelům, včlenil jeho př́běh s utajenou účastí v literárním životě Čech, nabyla by i těžce zakoušená internace protipól opovážlivého činu ve prospěch národní kultury.

O sklonu J. V. Friče pozměňovat v pozdních písemných svědectvích své starší jednání ve vlastní prospěch se v české kulturní paměti leccos tradovalo. V začátku sporů o smysl českých dějin vyzval historik Jan Heidler k tomu, rozlišovat ve Fričových Pamětech smyšlenku od mapování původních osobních postojů a činů. Zastával názor, že Fričovy Paměti jako celek vyznačuje ,,idealizující sebepojetí” jejich autora. Vysvětluje to jeho psychickým ustrojením:

Frič nedovedl viděti nazpět minulost, jaká byla, jeho temperament a fantazie jí dávaly barvu přítomnosti, která jej právě tísnila; /další část věty podtržena/ on promítal názory a hodnoty let osmdesátých do revoluce 1848 (Heidler 1912, s. 46).

Dále historik upřesňuje:

[Frič] Staví svoji osobu v popředí ,radikální strany“ roku 1848 [...], jako by byl býval jedním z vůdců radikálů, vlastně jejich vůdcem... (Heidler 1912, s. 50),

ale on byl v r. 1848 ,jen literátem a pak studentem”, o politiku tenkrát nedbal; ,nenapsal ani jednoho článku do novin, nepromluvil ani na jediné politické schůzi" (Heidler 1912, s. 51); v studentském hnutí ho prý zajímalo jen svatodušní povstání. - Podle Heidlera tedy Frič, který se po návratu do Čech 1879 přihlásil k mladočeské straně, v Pamětech zkreslil účast „radikální strany” v roce 1848, zveličil své postavení v ní, ,promítl veliký státoprávní a demokratický boj obou národních stran z let osmdesátých do revolučního roku 1848" (Heidler 1912, s. 59). Snad nepsal nepravdu úmyslně, prripouští znalý historik; činil tak ovšem ve svůj osobní prospěch ve snaze získat si po letitém vyloučení z rakouských zemí včetně Čech - po návratu do Prahy ochranu mladočeské strany, k níž se přihlásil. Pro historickou cenu zpráv (odpovídá Heidler o málo později svému oponentovi H. Traubovi, který spěchal J. V. Friče obhájit) „Nemá význam, zdali byla nepravda napsána úmyslně či neúmyslně, rozhoduje, že je to nepravda. Úmyslnost či neúmyslnost napsání nepravdy má význam pro ocenění povahy autorovy" (Heidler 1913, s. 447). 
Naše ohledání literárního pole v prvních dnech a týdnech, kdy tam jako novinka vstoupila Lada Nióla, přistihlo Friče dychtícího po nejvyšším uznání v národní kultuře, kde by mu nestínil Karel Havlíček. Jde ve své „rekonstrukci” tak daleko, že plodný rozruch, který zamlada svým opovážlivým almanachem vyvolal, pozdním převyprávěním v Pamětech odsoudil málem k zapomenutí.

Ale třeba se mu naskytla př́ležitost upotřebit svoji zkušenost s $L a$ dou Niólou ku prospěchu nastupující generace, když pomáhal při vydání almanachu Máj (1858)? Toto manifestační vystoupení literárně průbojné mládeže vyšlo jen čtyři roky po Ladě Nióle; ovšem tehdy se již česká společnost pomalu, ale jistě zbavovala zátěži z dob bachovské reakce, přibývalo důvěry ve všeobecný pokrok a volnost v umění, jež tomuto vzestupu slouží i ve prospěch svůj, svých tvưrců a všeho světa. Generace literárně nadaných lidí, kteří v datu svého narození měli rok 1830 a léta nejblíž následující (někdy kolem 1848 se začali rozhližžet po životě a nedlouho nato hledali, kde uveřejňovat své prvotiny - Nerudova báseň $Z$ času za živa pohřbených pochází již z roku 1854), se mohla dychtivě chápat pomocné ruky, kterou jí nabídl světem zběhlý a na literárním parketu již ostř́lený třicátník, $v$ ten čas ještě žijící v Praze...

S čím však iniciátor Lady Nióly a pamětník jejího přijetí od sklonku roku 1854 do jara 1855 své pokračovatele rozhodně neobeznámil, bylo odmítavé hodnocení jeho programu z pera K. Havlíčka, v rukopisu uchované. Znát toto Upř́mné mínění či o něm pouze vědět, mohl být nástup májovců průbojnější a rukopisy jednotlivých spoluautorů almanachu diferencované ještě jinak, než jsou. Pravda: konvergence začátečníků kolem J. Nerudy k Havlíčkovi tu existovala: Májovci si svého znovu a znovu zapovídaného předchůdce hleděli přibližit tím, že ve svých tiskových orgánech i jinak publikovali jeho básně, dosud šírené hlavně v opisech. Ale vědět o jeho Upřimném minění, byla by se tato návaznost utvářela ofenzívně.

\section{Literatura}

F r i č J. V., 1891, Paměti. Část druhá. Sv. 2, Praha.
H a v lí č e k B o r o v s ký K., 1955, O literatuře; red. Jaromír Bělič, Jiří Skalička, Praha: Československý spisovatel.

H e i d l e r J., 1912, Kritika Pamětí Josefa Václava Friče, „Český časopis historický” XIX, 1913, s. 38-59.

H e i d l e r J., Slovo o hodnotě Pamětí Fričových. (Odpověd'...), „Nová doba” 20, 1913, s. 445-447.

H o l e č e k J., 1912, Havličkovo Upř́mné miněni o almanachu Lada Nióla, „Časopis pro moderni filologii" 2 , Praha.

Na toto nové uveřejnění Havlíčkova rukopisu (když na vydání z roku 1912 ani znalci, ani širší obec ctitelů nereagovali), důrazně upozornil časopis Zvon, 1935.

Neznámý rukopis Karla Havlíčka, 1935, „Zlín” 4, č. 1, s. 3-4.

Š t ú r L., 1956, K přátelům, k bratrům, Slovenská knihovna sv. 3, sest. Z. Sojková, Praha: SNKLHU. 